\author{
Agnieszka SIEDLECKA ${ }^{1}$ \\ Jarosław ŻBIKOWSKI ${ }^{2}$ \\ Agnieszka SMARZEWSKA ${ }^{3}$ \\ Marian STELMACH ${ }^{4}$
}

\title{
NIEPELNOSPRAWNY JAKO AKTYWNY UCZESTNIK RYNKU PRACY
}

Problematyka niepełnosprawności stanowi ważny element dyskusji społecznej na temat rynku pracy, szczególnie w zakresie aktywności zawodowej zasobów kapitałowych. Aktywność osób niepełnosprawnych zależy od wielu czynników o charakterze społecznym i ekonomicznym. Wpływ na nią mają uwarunkowania związane zarówno z samą niepełnosprawnością, jak i jej rodzajem i stopniem. Nie bez znaczenia są również czynniki o charakterze makroekonomicznym, odnoszące się do całego systemu gospodarczego w kraju, wynikające między innymi z prawa ułatwiającego zatrudnianie niepełnosprawnych w zakresie korzyści osiąganych przez pracodawców.

Istotną funkcję w aktywności zawodowej osób niepełnosprawnych z obszarów wiejskich pełnią ich gospodarstwa rolne. W zdecydowanej większości to one są źródłem dodatkowych dochodów, niewątpliwie wpływając na większą stabilność finansową gospodarstw domowych osób niepełnosprawnych, tym bardziej w warunkach, w których znaczny odsetek zawieranych z nimi umów o pracę to umowy na czas określony.

Celem opracowania jest ocena sytuacji pracujących niepełnosprawnych na podstawie analizy następujących cech: główne i dodatkowe miejsce pracy osoby niepełnosprawnej, formy zatrudnienia, a także sposoby poszukiwania pracy. Artykuł powstał w oparciu na analizie wyników badań przeprowadzonych w ramach projektu badawczego „Determinanty aktywności zawodowej osób niepełnosprawnych zamieszkałych na obszarach wiejskich" współfinansowanego przez PFRON (Umowa nr 3/4/WRP/B/08). Projekt opierał się na realizacji badań jakościowych i ilościowych. Badania jakościowe przeprowadzono na grupie 150 podmiotów gospodarczych, w okresie od lipca do października 2011 r. Badania ilościowe przeprowadzono we wszystkich szesnastu województwach na terenie kraju, z uwzględnieniem specyfiki społeczno-ekonomicznej regionów, od czerwca 2010 r. do czerwca 2011. W realizacji badań ilościowych wykorzystano technikę ankietową. Kwestionariusz ankiety przeprowadzony został wśród 5000 osób niepełnosprawnych z prawnie orzeczonym stopniem niepełnosprawności.

Słowa kluczowe: niepełnosprawność, rynek pracy, aktywność zawodowa.

\footnotetext{
${ }^{1}$ Dr Agnieszka Siedlecka, Instytut Ekonomii i Zarządzania, PSW im. Papieża Jana Pawła II w Białej Podlaskiej, Biała Podlaska, ul. Sidorska 95/97, 21-500 Biała Podlaska, e-mail: a.siedlecka@dydaktyka.pswbp.pl (autor korespondencyjny).

${ }^{2}$ Doc. dr Jarosław Żbikowski, Instytut Turystyki i Rekreacji, PSW im. Papieża Jana Pawła II w Białej Podlaskiej, Biała Podlaska

${ }^{3}$ Dr inż. Agnieszka Smarzewska, Instytut Ekonomii i Zarządzania, PSW im. Papieża Jana Pawła II w Białej Podlaskiej, Biała Podlaska

${ }^{4}$ Dr Marian Stelmach, Instytut Turystyki i Rekreacji, PSW im. Papieża Jana Pawła II w Białej Podlaskiej, Biała Podlaska
} 


\section{WPROWADZENIE}

Problematyka niepełnosprawności stanowi ważny element dyskusji społecznej na temat rynku pracy, szczególnie w zakresie aktywności zawodowej zasobów kapitałowych. Aktywność osób niepełnosprawnych zależy od wielu czynników o charakterze społecznym i ekonomicznym. Wpływ na nią mają uwarunkowania związane zarówno z samą niepełnosprawnością, jak i jej rodzajem i stopniem. Nie bez znaczenia są również czynniki o charakterze makroekonomicznym, odnoszące się do całego systemu gospodarczego w kraju, wynikające między innymi z prawa ułatwiającego zatrudnianie niepełnosprawnych w zakresie korzyści osiąganych przez pracodawców.

Aktywność osób niepełnosprawnych na rynku pracy wiąże się z podejmowaniem przez nich pracy, stawaniem przed wyzwaniami związanymi z codziennym wysiłkiem dojazdów do pracy i jej wykonywania.

Ważnym aspektem aktywności zawodowej jest poszukiwanie nowoczesnych rozwiązań wynikających z wykorzystywania elastycznych form zatrudniania. Stwarza to możliwość zdobywania zatrudnienia przez niepełnosprawnych.

\section{DEFINICJA I KLASYFIKACJA NIEPELNOSPRAWNOŚCI}

W literaturze przedmiotu można znaleźć wiele definicji terminu „niepełnosprawność”. Mnogość definicji związana jest z różnorodnością podejść do problematyki, wynikających z jej interdyscyplinarnego charakteru.

Według obowiązującej ustawy o rehabilitacji zawodowej i społecznej oraz zatrudnianiu osób niepełnosprawnych niepełnosprawność oznacza ,trwałą lub okresową niezdolność do wypełniania ról społecznych z powodu stałego lub długotrwałego naruszenia sprawności organizmu, w szczególności powodującą niezdolność do pracy"5. Definicja Światowej Organizacji Zdrowia wskazuje w większym stopniu ukierunkowanie na różne sfery życia człowieka, zarówno społeczne, jak i zawodowe. Według niej osoba niepełnosprawna to osoba o naruszonej sprawności funkcjonalnej lub aktywności życiowej w stopniu utrudniającym odgrywanie ról społecznych.

Problem niepełnosprawności może być postrzegany w różnorodny sposób. Jedno z podejść prezentuje International Classification of Functioning, Disability and Health (ICF), które „zapewnia wielowymiarowe podejście do klasyfikacji funkcjonowania i niepełnosprawności jako interaktywnego i ewolucyjnego procesu" ${ }^{6}$. Wskazuje na dwa modele pozwalające na zrozumienie i wyjaśnienie problematyki niepełnosprawności: model medyczny i społeczny. Model medyczny koncentruje się na niepełnosprawności jako problemie osobistym jednostki. Stan ten wywołany jest bezpośrednią przyczyną związaną $\mathrm{z}$ chorobą lub urazem. W wyniku tego jednostka potrzebuje opieki medycznej w postaci leczenia, w efekcie czego postępowanie w niepełnosprawności ukierunkowane jest na wyleczenie lub też dostosowanie jednostki. Równie ważnym celem jest dążenie do zmiany zachowania niepełnosprawnej jednostki ${ }^{7}$.

\footnotetext{
${ }^{5}$ Ustawa o rehabilitacji zawodowej i społecznej oraz zatrudnianiu osób niepełnosprawnych z 27 sierpnia $1997 \mathrm{r}$. (DzU z 2011 r. nr 127, poz. 721 ze zm.).

${ }^{6}$ ICF, Międzynarodowa Klasyfikacja Funkcjonowania, Niepełnosprawności i Zdrowia, World Health Organization Geneva 2001, Centrum Systemów Informacyjnych Ochrony Zdrowia 2009, s. 18.

${ }^{7}$ Ibidem, s. 20.
} 
Drugie podejście - model społeczny niepełnosprawności - postrzega omawiane zagadnienie z punktu widzenia zauważania niepełnosprawności jako problemu społeczeństwa. To środowisko społeczne odpowiada za tworzenie odpowiednich warunków dla pełnego uczestnictwa niepełnosprawnych we wszystkich obszarach życia społecznego. Według omawianego podejścia niepełnosprawność nie jest cechą jednostki, jest „raczej złożonym zbiorem stanów, z których wiele jest tworem środowiska społecznego"8.

Na zagadnienie wykluczenia w literaturze przedmiotu zwrócono uwagę już znacznie wcześniej. Wskazano między innymi, że „społeczeństwo upośledza niepełnosprawnych fizycznie. Niepełnosprawność znajduje się powyżej naszych zaburzeń, jest nadbudowana nad ułomnościami przez fakt, że niepełnosprawni są izolowani. Poza izolacją dochodzi do wykluczenia z uczestnictwa w życiu społecznym”9.

Wykluczenie społeczne ma pośrednie odzwierciedlenie w aktywności niepełnosprawnych. Aktywności szeroko pojmowanej, w aspekcie zarówno ekonomicznym, jak i społecznym, związanej z rynkiem pracy, spędzaniem czasu wolnego oraz mobilnością.

\section{AKTYWNOŚĆ EKONOMICZNA NIEPELNOSPRAWNYCH WEDLUG DA- NYCH GLÓWNEGO URZĘDU STATYSTYCZNEGO}

Analizę zatrudnienia niepełnosprawnych przeprowadzono na podstawie danych Głównego Urzędu Statystycznego prezentowanych w opracowaniu Osoby niepetnosprawne na rynku pracy w 2011 roku. Opracowanie zawiera wyniki badań modułowych realizowanych łącznie z Badaniem Aktywności Ekonomicznej Ludności. Dodatkowo wykorzystano inne dane zawarte w materiałach GUS.

W wyniku analizy zebranych danych wskazano, że współczynnik aktywności zawodowej niepełnosprawnych wynosi 17,2\%. Wielkość ta zasadniczo różni się dla aktywności zawodowej ogółu ludności, gdzie wskaźnik kształtuje się na poziomie 56\%. Podobnie bardzo znaczące rozbieżności wystąpiły w wypadku wskaźnika zatrudnienie. Jego wielkość w odniesieniu do niepełnosprawnych była trzykrotnie niższa w porównaniu z ludnością ogółem (tab. 1).

Tabela 1. Wybrane wskaźniki aktywności na rynku pracy dla osób niepełnosprawnych według kryterium prawnego oraz ludności ogółem (\%)

\begin{tabular}{|l|l|l|}
\hline Wyszczególnienie & Ludność ogólem & Osoby niepelnosprawne \\
\hline $\begin{array}{l}\text { Współczynnik aktywności } \\
\text { zawodowej }\end{array}$ & 56,0 & 17,2 \\
\hline Wskaźnik zatrudnienia & 50,7 & 14,8 \\
\hline Stopa bezrobocia & 9,5 & 13,7 \\
\hline
\end{tabular}

Źródło: Osoby niepetnosprawne na rynku pracy w 2011 roku, Główny Urząd Statystyczny, Warszawa 2012, s. 29.

Kolejnym miernikiem opisującym sytuację ludności na rynku pracy jest stopa bezrobocia. Wielkość ta była wyższa w grupie niepełnosprawnych - 13,7\% w porównaniu z ogółem ludności.

\footnotetext{
${ }^{8}$ Ibidem.

${ }^{9}$ The Union of the Physically Impairedagainst Segregationandthe Disability Alliance, Fundamental Principles of Disability, London 1976, s. 4, http://disability-studies.leeds.ac.uk/files/library/UPIAS-fundamentalprinciples.pdf (dostęp: 12.05.2013).
} 
Analizując te wskaźniki z uwzględnieniem zmiennych terytorialnych, można zaobserwować, że sytuacja niepełnosprawnych, zarówno w mieście, jak i na obszarach wiejskich, jest zbliżona. Wskaźnik zatrudnienia osób niepełnosprawnych w wieku 16 lat i więcej w 2011 r. był wyższy wśród mieszkańców wsi jedynie o 0,1 w porównaniu do osób niepełnosprawnych mieszkających w miastach (rys 1). Współczynnik aktywności zawodowej jest wyższy w miastach 17,8\% niż na obszarach wiejskich 16,3\%. Różnica ta jest również niewielka.

Rys. 1. Aktywność zawodowa osób niepełnosprawnych w wieku produkcyjnym w latach 2001-2011

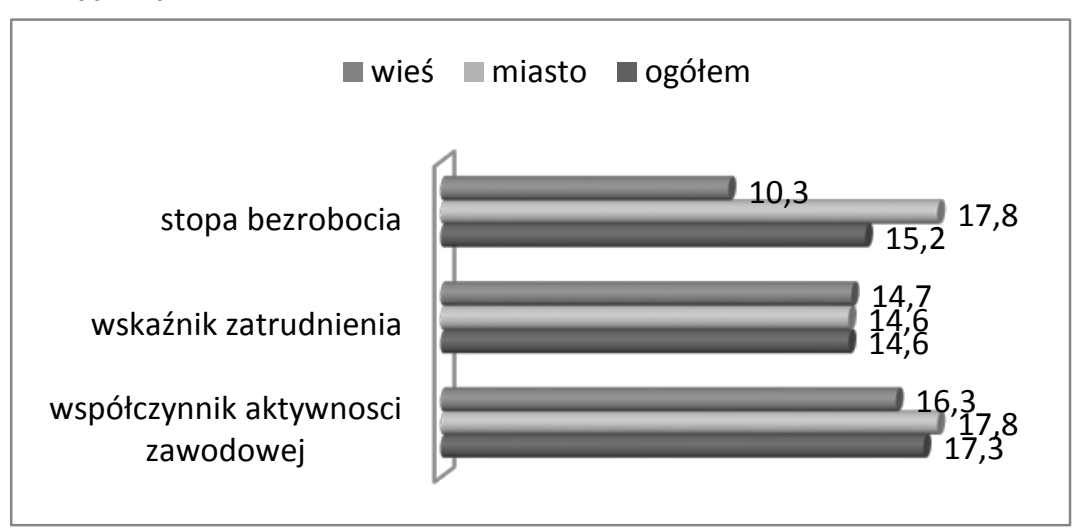

Źródło: Badanie Aktywności Ekonomicznej Ludności, GUS, Warszawa.

Znacząco różni obszary wiejskie i miasta stopa bezrobocia wśród niepełnosprawnych. Jej poziom jest istotnie wyższy w miastach $(17,8 \%)$ w porównaniu z obszarami wiejskimi - 10,3\%. Z pozoru sytuacja niepełnosprawnych na wsi ze względu na tę wielkość jest lepsza. Jednakże należy pamiętać, że niższy poziom bezrobocia rejestrowanego na obszarach wiejskich wynika z występowania tam wysokiego poziomu bezrobocia ukrytego.

Wśród niepełnosprawnych pracowników dominującą grupę stanowią pracownicy najemni. W analizowanym roku ich udział na obszarach wiejskich wynosił 40,56\%. Był zdecydowanie mniejszy w porównaniu z danymi ogólnymi - 58,64\% (rys. 2). Wśród niepełnosprawnych aktywnych na rynku pracy ważne miejsce zajmują pracownicy użytkujący gospodarstwo rolne. Według danych GUS w 2011 r. osoby takie na obszarach wiejskich stanowiły $10 \%$ ogółu zatrudnionych niepełnosprawnych. Drugim co do ważności miejscem pracy wśród niepełnosprawnych na obszarach wiejskich jest gospodarstwo rolne. Stanowiło ono miejsce zatrudnienia dla ponad 13\% zatrudnionych osób niepełnosprawnych. 
Rys. 2. Struktura zatrudnienia osób niepełnosprawnych w $2011 \mathrm{r}$.

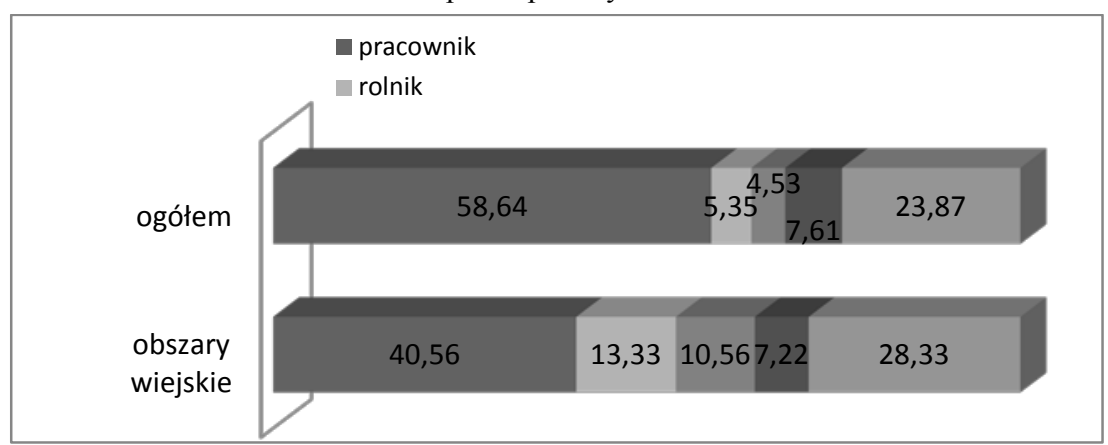

Źródło: Badanie Aktywności Ekonomicznej Ludności, GUS, Warszawa.

Najniższa aktywność wystąpiła w wypadku pracujących na własny rachunek. Niepełnosprawni prowadzący własną działalność gospodarczą w roku 2011 według danych GUS stanowi niespełna 7\%. Samozatrudnienie jest szczególnym przejawem aktywności zawodowej nie tylko niepełnosprawnych.

Analizując aktywność ekonomiczną niepełnosprawnych należy wskazać, że znaczącą ich grupę stanowią osoby bierne zawodowo. Na sytuację niepełnosprawnych na rynku pracy wpływa wiele czynników, wśród nich należy wymienić te o charakterze makroekonomicznym, w zakresie sytuacji gospodarczej kraju oraz odnoszące się bezpośrednio do osoby niepełnosprawnej, np. brak aktywności zawodowej oraz niechęć do poszukiwania pracy.

\section{METODOLOGIA BADAŃ}

Celem opracowania jest ocena sytuacji pracujących niepełnosprawnych na podstawie analizy następujących cech: główne i dodatkowe miejsce pracy osoby niepełnosprawnej, formy zatrudnienia, a także sposoby poszukiwania pracy. Artykuł powstał w oparciu na analizie wyników badań przeprowadzonych w ramach projektu badawczego „Determinanty aktywności zawodowej osób niepełnosprawnych zamieszkałych na obszarach wiejskich” współfinansowanego przez PFRON (Umowa nr 3/4/WRP/B/08). Projekt opierał się na realizacji badań jakościowych i ilościowych. Badania jakościowe przeprowadzono na grupie 150 podmiotów gospodarczych od lipca do października $2011 \mathrm{r}$.

Badania ilościowe przeprowadzono we wszystkich szesnastu województwach na terenie kraju, z uwzględnieniem specyfiki społeczno-ekonomicznej regionów, od czerwca 2010 r. do czerwca 2011. W realizacji badań ilościowych wykorzystano technikę ankietową. Kwestionariusz ankiety wypełniło 5000 niepełnosprawnych z prawnie orzeczonym stopniem niepełnosprawności. Operat losowy stanowiący podstawę doboru próby badawczej stanowiły dane pochodzące z Warsztatów Terapii Zajęciowej oraz Powiatowych Centrów Pomocy Rodzinie $\mathrm{z}$ terenu całej Polski. Celem badań realizowanych w ramach 
projektu była próba wieloaspektowej analizy uwarunkowań aktywności zawodowej osób niepełnosprawnych zamieszkałych na obszarach wiejskich ${ }^{10}$.

\section{ANALIZA WYNIKÓW BADAŃ}

W badanej grupie 5000 niepełnosprawnych osoby pracujące stanowiły $27,2 \%$ zbiorowości (1359 osób). Przeprowadzone badania wskazały, że pracujące osoby niepełnosprawne zatrudniane są najczęściej w firmach prywatnych $(34,54 \%)$, rzadziej w zakładach pracy chronionej $(19,53 \%)$ i firmach sektora państwowego (15,69\%). Zdecydowanie mniej w spółdzielczości inwalidzkiej czy zakładach aktywności zawodowej. Nieliczni prowadzą własną działalność gospodarczą lub gospodarstwo rolne (rys. 3).

Rys. 3. Główne miejsce pracy osób niepełnosprawnych z obszarów wiejskich (dane dla Polski)

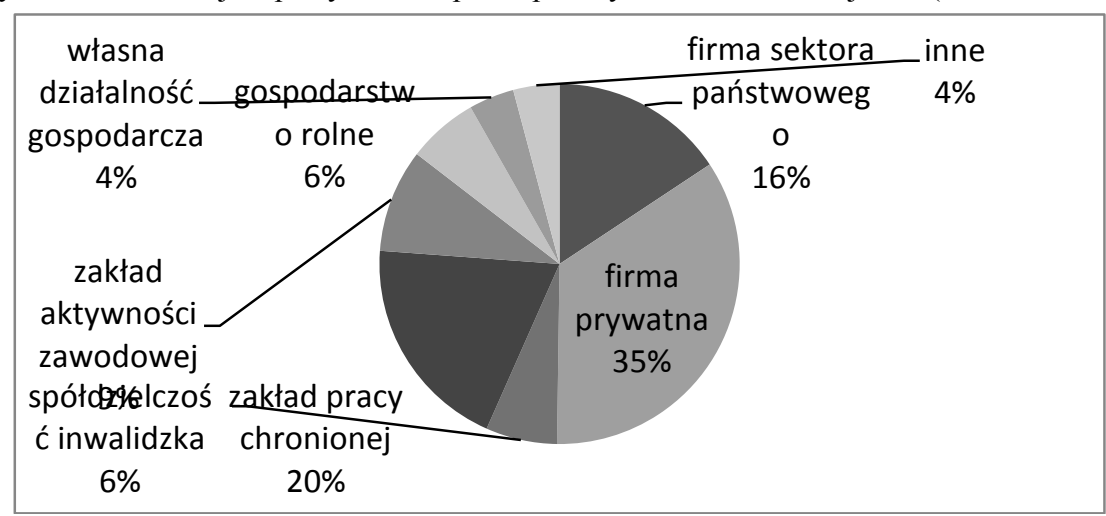

Źródło: badania ewłasne.

Identyfikując czynniki, które wpływają na główne miejsce zatrudnienia, można przypuszczać, że są nimi uwarunkowania terytorialne, określone typem gminy (wiejska lub wiejsko-miejska). Istnieje statystyczna zależność pomiędzy głównym miejscem pracy a rodzajem gminy. Test chi-kwadrat wyniósł 44,636 na poziomie istotności 0,000 . Z kolei współczynnik V-Cramera wskazuje na występowanie zależności na poziomie $\mathrm{V}=0,0183$, co pozwala oszacować siłę zależności jako słabą.

Analizując miejsce zatrudnienia z uwzględnieniem rodzaju gminy, w jakiej mieszkali respondenci, można zaobserwować następujące różnice:

- wyższy o 6 punktów procentowych poziom zatrudnienia niepełnosprawnych w firmach prywatnych na terenie gmin miejsko-wiejskich,

- $\quad$ wyższy o 6 punktów procentowych poziom zatrudnienia niepełnosprawnych w zakładach pracy chronionej na terenie gmin miejskowiejskich,

\footnotetext{
10 J. Żbikowski, D. Dąbrowski, M. Kuźmicki, Determinanty aktywności zawodowej osób niepetnosprawnych zamieszkałych na obszarach wiejskich, Raport z badań, t. I, Państwowa Szkoła Wyższa im. Papieża Jana Pawła II w Białej Podlaskiej, Państwowy Fundusz Rehabilitacji Osób Niepełnosprawnych, Biała Podlaska 2012, s. 82.
} 
- większy o blisko $10 \%$ udział zatrudnionych w zakładach aktywności zawodowej respondentów z gmin wiejskich,

- większy odsetek pracujących niepełnosprawnych zatrudnionych w firmach państwowych na terenie gmin wiejskich.

Różnice te zestawiono w tabeli 2.

Tabela 2. Główne miejsce pracy osób niepełnosprawnych z obszarów wiejskich według typu gminy

\begin{tabular}{|l|r|r|r|}
\hline Główne miejsce pracy & \multicolumn{2}{|c|}{ Typ gminy } & \multirow{2}{*}{ Ogółem } \\
\cline { 2 - 3 } & Gmina wiejska & $\begin{array}{c}\text { Gmina miejsko- } \\
\text { wiejska }\end{array}$ & \\
\hline Firma sektora państwowego & 16,3 & 14,1 & 15,7 \\
Firma prywatna & 32,9 & 38,6 & 34,5 \\
Spółdzielczość inwalidzka & 5,9 & 7,7 & 6,4 \\
Zakład pracy chronionej & 17,7 & 23,9 & 19,5 \\
Zakład aktywności zawodowej & 12,2 & 2,3 & 9,3 \\
Gospodarstwo rolne & 7,3 & 4,1 & 6,3 \\
Własna działalność gospodarcza & 4,1 & 4,1 & 4,1 \\
Inne & 3,7 & 5,1 & 4,1 \\
Ogółem & 100,0 & 100,0 & 100,0 \\
\hline
\end{tabular}

Źródło: badania własne.

Jednym z instrumentów pozwalających gospodarstwom domowym na osiąganie oczekiwanego poziomu dochodów są działania związane z dywersyfikacją dochodów. W badanej grupie niepełnosprawnych może to następować poprzez podejmowanie dodatkowego zatrudnienia. Należy zaznaczyć, że samo poszukiwanie dodatkowego miejsca pracy związane jest z szeroko pojętą aktywnością zawodową. W grupie 1359 pracujących respondentów jedynie niespełna $9 \%$ wskazało, że ma dodatkowe miejsce pracy.

Dominującym w badanej populacji dodatkowym miejscem pracy było gospodarstwo rolne (rys. 4). Ponad $44 \%$ pracujących niepełnosprawnych z obszarów wiejskich wskazało, że było to dodatkowe miejsce pracy. Blisko $20 \%$ respondentów deklarowało „inne” miejsca pracy dodatkowej. Można przypuszczać, że jest to praca dorywcza, nieoparta na umowie o pracę, prawdopodobnie $\mathrm{w}$ tzw. szarej strefie. Ten sam odsetek pracujących niepełnosprawnych pracuje dodatkowo w firmach prywatnych, a pozostałe miejsca zatrudnienia mają znaczenie marginalne. 
Rys. 4. Dodatkowe miejsce pracy osób niepełnosprawnych z obszarów wiejskich (dane dla Polski)

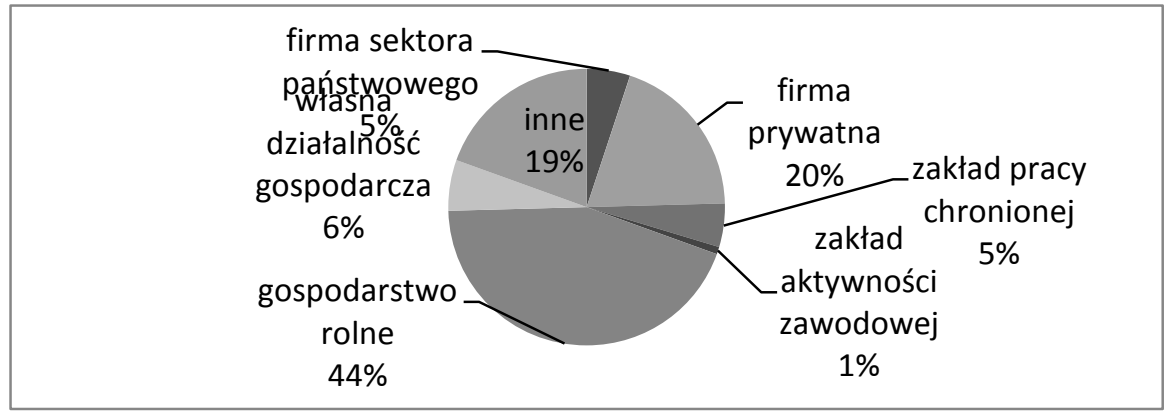

Źródło: badania własne.

Interesujących danych dostarcza analiza dodatkowego miejsca pracy osób niepełnosprawnych z obszarów wiejskich w podziale na rodzaje gmin (tab. 3). W gminach wiejskich dominującym dodatkowym miejscem pracy jest gospodarstwo rolne. Odsetek ten jest o około 4\% większy niż w gminach miejsko-wiejskich. Kolejną znaczącą różnicą jest fakt, że w wypadku gmin wiejskich znacznie częściej prowadzenie działalności gospodarczej dostarcza dodatkowego dochodu. Również w wypadku niepełnosprawnych zamieszkujących gminy wiejskie firmy sektora państwowego znacznie częściej stanowią źródło dodatkowego dochodu.

Tabela 3. Dodatkowe miejsce pracy osób niepełnosprawnych z obszarów wiejskich (dane dla gmin)

\begin{tabular}{|l|r|r|r|}
\hline \multirow{2}{*}{ Dodatkowe miejsce pracy } & \multicolumn{2}{|c|}{ Typ gminy } & \multirow{2}{*}{ Ogółem } \\
\cline { 2 - 3 } & $\begin{array}{c}\text { Gmina wiej- } \\
\text { ska }\end{array}$ & $\begin{array}{c}\text { Gmina miej- } \\
\text { sko-wiejska }\end{array}$ & \\
\hline Firma sektora państwowego & 7,8 & & 5,1 \\
Firma prywatna & 14,3 & 29,3 & 19,5 \\
Zakład pracy chronionej & 5,2 & 4,9 & 5,1 \\
Zakład aktywności zawodowej & 1,3 & $-1,5$ & 0,8 \\
Gospodarstwo rolne & 45,5 & 41,5 & 44,1 \\
Własna działalność gospodarcza & 7,8 & 2,4 & 5,9 \\
Inne & 18,2 & 22,0 & 19,5 \\
Ogółem & 100,0 & 100,0 & 100,0 \\
\hline
\end{tabular}

Źródło: badania własne.

Podejmowanie zatrudnienia wiąże się z analizą kosztów alternatywnych (koszt potencjalnych utraconych możliwości) samej osoby zatrudnianej. Jednym z czynników, który może mieć wpływ na decyzję ewentualnego pracownika, jest forma zatrudnienia. W obecnej sytuacji społeczno-gospodarczej znaczenia nabierają elastyczne formy zatrudniania w postaci umów o dzieło, umów zlecenie. Jednym z obszarów stanowiących przedmiot zainteresowania niniejszego opracowania jest analiza formy zatrudnienia niepełnosprawnych pracowników. 
Uzyskane wyniki badań wskazują, że badani respondenci w znaczącej grupie zatrudniani są na podstawie umowy o pracę. Blisko $80 \%$ badanych pracujących niepełnosprawnych zadeklarowało, że jest zatrudniona w tej formie. Różnicuje je tylko postać tej umowy: 44\% zatrudnionych jest na podstawie umowy o pracę na czas nieokreślony, pozostała grupa to pracownicy zatrudnieni na czas określony. Co dziesiąty pracujący respondent wskazał, że pracuje na własny rachunek. Pozostałe formy zatrudniania mają marginalne znaczenie w badanej grupie: umowa o dzieło $1 \%$ pracujących, umowa zlecenie 5,5\%, umowa ustna $3,4 \%$.

Nie występują statystyczne zależności pomiędzy typem gminy zamieszkałej przez badanych a formą zatrudnienia. Jednakże należy zaznaczyć, że umowy na czas nieokreślony jako forma zatrudnienia osób niepełnosprawnych $\mathrm{z}$ obszarów wiejskich są stosowane częściej w gminach miejsko-wiejskich niż w gminach wiejskich. Odwrotna sytuacja zachodzi w wypadku umów o pracę na czas określony. Natomiast umowy o dzieło i umowy zlecenia dotyczą $\mathrm{w}$ większym stopniu niepełnosprawnych $\mathrm{z}$ gmin miejsko-wiejskich, natomiast samozatrudnienie występuje częściej w gminach wiejskich (rys. 5).

Rys. 5. Forma zatrudnienia niepełnosprawnych z obszarów wiejskich w poszczególnych regionach

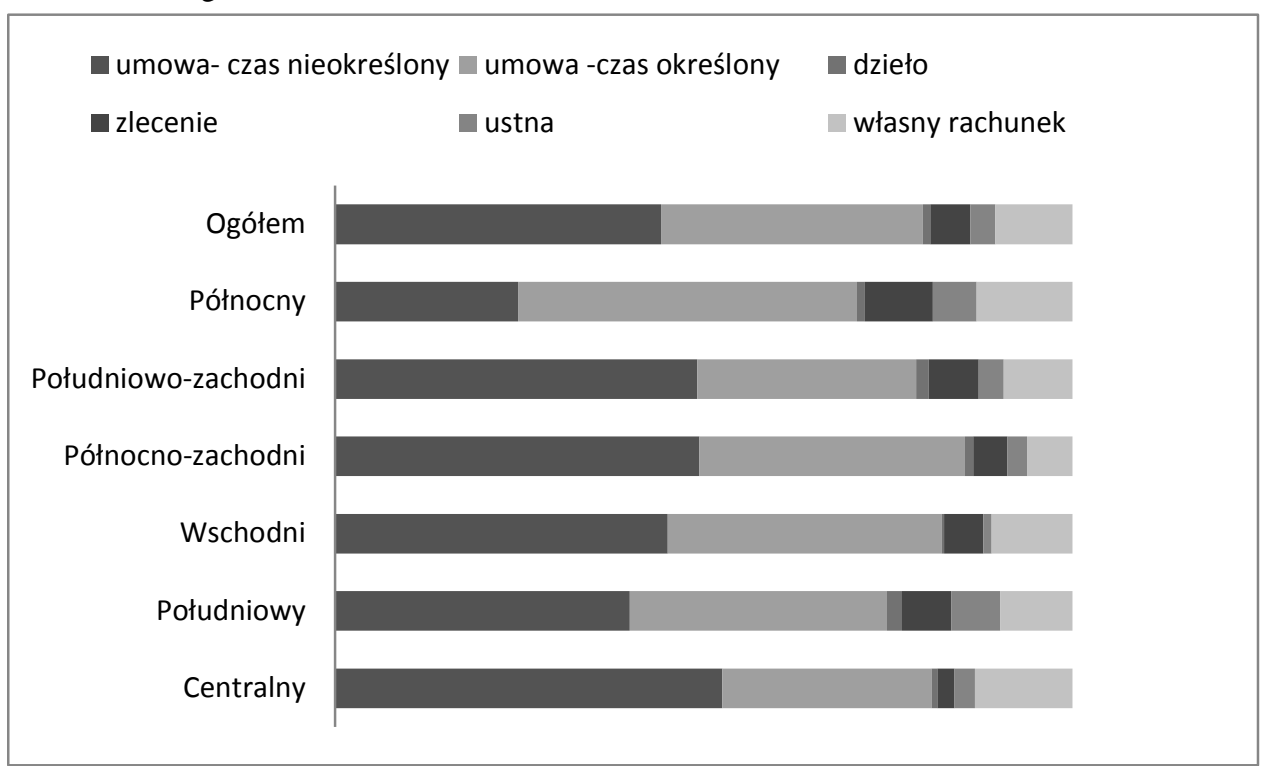

Źródło: badania własne.

Poszukiwanie pracy jest związane z podejmowaniem wielu różnorodnych działań zmierzających do osiągnięcia sukcesu, czyli znalezienia zatrudnienia. Wszelkie działania zmierzające do osiągnięcia tego głównego celu są wynikiem aktywności zainteresowanych pracowników. W badanej populacji pracujących osób niepełnosprawnych zamieszkałych na obszarach wiejskich zdecydowana większość znalazła pracę samodzielnie, bezpośrednio starając się o nią u przyszłego pracodawcy (47\%). Podejmowanie działań związanych z bezpośrednim kontaktem z potencjalnym pracodawcą jest najwyższą formą aktywności. Innym sposobem na uzyskanie zatrudnienia jest skorzystanie z pomocy in- 
nych osób, w tym znajomych i rodziny. Blisko 1/4 biorących udział w badaniu respondentów pracujących wskazała na tę formę podejmowania zatrudnienia. Analizując różne metody pozyskiwania pracy $\mathrm{z}$ uwzględnieniem ważności w badanej grupie niepełnosprawnych, należy wskazać samozatrudnienie. Ponad 10\% pracujących niepełnosprawnych respondentów podejmuje trud prowadzenia własnej działalności gospodarczej. Aktywność ta jest szczególnie wysoka na obszarach gmin wiejskich.

Uzyskane wyniki badań wskazują, że działalność instytucji rynku pracy w badanej grupie respondentów nie stanowiła wiodącej metody na znalezienie pracy (rys. 6). Powiatowe Urzędy Pracy, biura pośrednictwa pracy oraz agencje doradztwa personalnego wskazało odpowiednio 8,3\% oraz 1,8\% badanych. Równie niepokojący jest niewielki odsetek wskazań organizacji pozarządowych działających na rzecz niepełnosprawnych. Jedynie 1,5\% pracujących niepełnosprawnych zadeklarowało, że znaleźli pracę dzięki tego rodzaju instytucjom.

Rys. 6. Sposoby poszukiwania pracy przez pracujące osoby niepełnosprawne z obszarów wiejskich (dane gmin wiejskich i miejsko-wiejskich)*

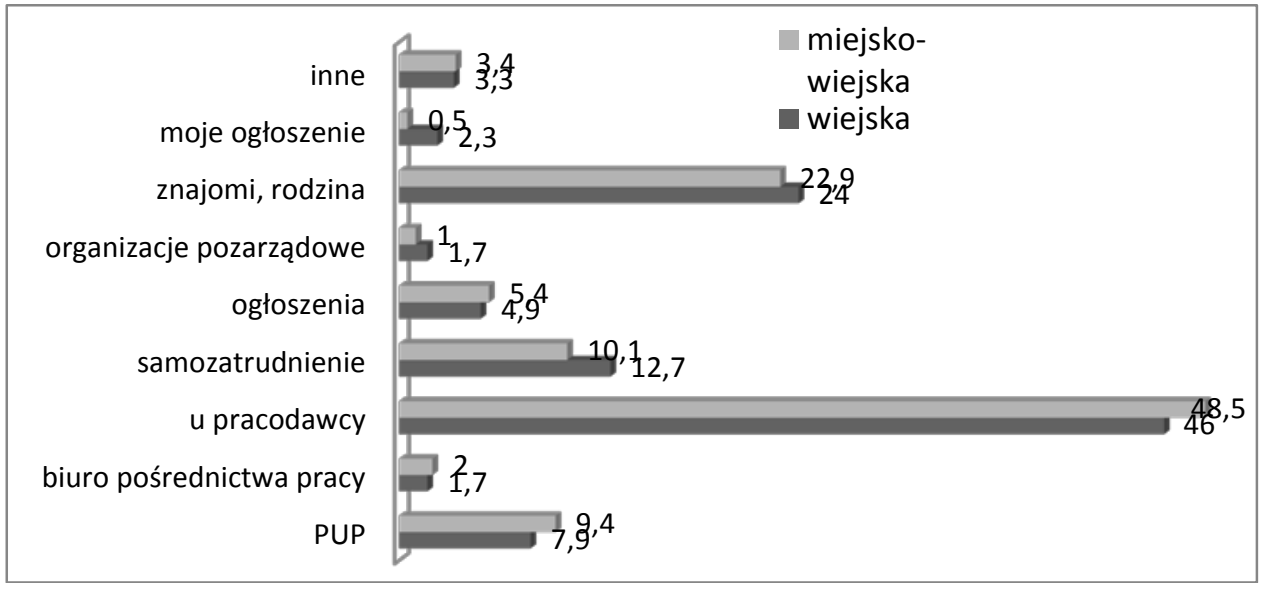

* Respondent mógł wybrać więcej niż jedną odpowiedź.

Źródło: badania własne.

Poszukując czynników wpływających na sposób znalezienia pracy, uwzględniono aspekt terytorialny, czyli podział na gminy wiejskie i miejsko-wiejskie. Analiza uzyskanego materiału empirycznego pozwoliła na stwierdzenie, że nie wystąpiły istotne statystycznie różnice pomiędzy typami gminy a metodami poszukiwania pracy przez respondentów. Jednakże warto zwrócić uwagę, że szukanie pracy bezpośrednio u pracodawcy jest nieco bardziej skuteczne w gminach miejsko-wiejskich, podobnie w wypadku znalezienia jej za pośrednictwem Powiatowego Urzędu Pracy. Osoby niepełnosprawne z gmin wiejskich częściej niż z gmin miejsko-wiejskich znajdują pracę dzięki pomocy rodziny lub znajomych, jak również zakładają własne firmy.

Warto zauważyć, że ekspansywne metody poszukiwania pracy, wymagające znacznego wkładu osoby zainteresowanej, były w badanej grupie wykorzystywane w bardzo nieznacznym stopniu. 


\section{PODSUMOWANIE I WNIOSKI}

Podsumowując, należy pozytywnie ocenić większy niż gminach miejsko-wiejskich udział samozatrudnienia występującego w gminach wiejskich. Jest to tym bardziej istotne, że np. pod względem zatrudnienia w zakładach pracy chronionej lepiej wypadają gminy miejsko-wiejskie, zwłaszcza $\mathrm{w}$ warunkach systematycznego zmniejszania się liczby miejsc pracy w sektorze państwowym.

Istotną funkcję $\mathrm{w}$ aktywności zawodowej osób niepełnosprawnych z obszarów wiejskich pełnią ich gospodarstwa rolne. W zdecydowanej większości to one są źródłem dodatkowych dochodów, niewątpliwie wpływając na większą stabilność finansową gospodarstw domowych osób niepełnosprawnych. Zwłaszcza gdy znaczny odsetek zawieranych z nimi umów o pracę to umowy na czas określony.

Mimo że stosunkowo duża część badanych pracujących osób niepełnosprawnych znalazła pracę samodzielnie, to sytuacji w zakresie sposobów poszukiwania pracy nie można ocenić pozytywnie. Zwraca uwagę znaczny odsetek tych badanych, którzy musieli skorzystać z pomocy rodziny lub znajomych, a także względnie niewielki tych, którzy skorzystali z usług Powiatowych Urzędów Pracy.

Należy zauważyć konieczność podjęcia działań w celu nawiązania kontaktu z pracodawcą przez osoby niepełnosprawne. Badania wykazały, że właściwie dzięki takiej formie aktywności blisko połowa badanych dostała szansę pracy.

\section{LITERATURA}

[1] ICF. Międzynarodowa Klasyfikacja Funkcjonowania, Niepetnosprawności i Zdrowia, World Health Organization, Geneva 2001, Centrum Systemów Informacyjnych Ochrony Zdrowia 2009.

[2] The Union of the Physically Impairedagainst Segregationandthe Disability Alliance, Fundamental Principles of Disability, London 1976, http://disability-studies.leeds.ac.uk/files/library/ UPIAS-fundamental-principles.pdf.

[3] Ustawa o rehabilitacji zawodowej i społecznej oraz zatrudnianiu osób niepełnosprawnych z 27 sierpnia 1997 r. (DzU z 2011 nr 127, poz. 721 ze zm.).

[4] Żbikowski J., Dąbrowski D., Kuźmicki M, Determinanty aktywności zawodowej osób niepetnosprawnych zamieszkatych na obszarach wiejskich, Raport z badań, t. I, Państwowa Szkoła Wyższa im. Papieża Jana Pawła II w Białej Podlaskiej, Państwowy Fundusz Rehabilitacji Osób Niepełnosprawnych, Biała Podlaska 2012.

\section{A DISABLED PERSON AS AN ACTIVE PARTICIPANT IN THE LABOUR MARKET}

The problem of disabilities is a crucial element of social discussion about the job market, especially within the vocational activities of capital reserves. The activity of disabled people depends on a variety of social and economic factors. It is influenced byconditionings connected with disability itself as well as its type and degree. It is also important to consider macroeconomic factors referring to the whole economic system of the country and arising from the law that facilitates the employment of the disabled, proving beneficial to employers. A substantial function in vocational activities of the disabled living in rural areas is served by their own homesteads which are most frequently the source of additional profits. This undoubtedly leads to a greater financial stability of households owned by the disabled, taking into account the fact they are most commonly on fixed term contracts. The purpose of the following article is to evaluate the situation of disabled workers considering the analysis 
of the following characteristics: main and additional workplace of a disabled person, forms of employment and methods of job search. The article has been written on the basis of the study conducted within the scope of research project entitled "Determinants of vocational activities amongst disabled people inhabiting rural areas", co-financed by PFRON (no. 3/4/WRP/B/08). The project was based on quantitative and qualitative research. The qualitative research was being carried out from July to October 2011, in 150 households. The quantitative research was being conducted from June 2010 to June 2011 in all 16 voivodeships, taking into consideration the regional socio-economic specificity. Questionnaires used to collect data were taken by 5000 people certified as disabled.

Keywords: disability, labour market, vocational activities.

DOI: 10.7862/rz.2014.mmr.22

Tekst złożono w redakcji: luty 2014

Przyjęto do druku: czerwiec 2014 